\title{
Orientation of The Cultural Organisation Activity and It's Development Path
}

\author{
Grzegorz KRZOS and Anna SCHNEIDER
}

Wrocław University of Economics and Business, Wrocław, Poland

Correspondence should be adressed to: Anna SCHNEIDER; anna.schneider@ue.wroc.pl

Received date: 27 August 2020; Accepted date: 17 December 2020; Published date: 15 February 2021

Academic Editor: Klaudia Przybysz

Copyright (C) 2021. Grzegorz KRZOS and Anna SCHNEIDER. Distributed under Creative Commons Attribution 4.0 International CC-BY 4.0

\begin{abstract}
The development of the organisation is a multi-dimensional trajectory and as such there is no specific classification for its description. Developing a theoretical model of the organisation's development based on its orientation can provide a clearer understanding and picture of the successes or issues faced in any given point of its' evolution. The purpose of the research is to identify the orientation elements describing the path of the cultural organisation development. Identifying and developing a theoretical model appears to be a fundamental component of the functioning of the cultural organisation's orientations, given that different organisations consist of various elements, which are utilised to describe their scope. The exploratory, single case study was conducted to determine whether the assumptions about these orientations made by the authors of the publication are correct. The following data analysis methods were used in the study: referring to theoretical assumptions and participant observation. The study confirmed that data are incomplete, but sufficient to describe the activities of the cultural organisation. The set of orientations including product, process, function, design, technology and innovation, geographic expansion, network orientation, will be the baseline for determining the cultural organisation's development path. The research results also show that the dimensions of cultural institution orientation are not the same as the assumptions made. This indicates the need for further in-depth research in this field and requires consideration of whether there is a common set of dimensions describing individual orientations.
\end{abstract}

Keywords: developmental path, cultural institution developmental path, organisational development, organisational orientation

Cite this Article as: Grzegorz KRZOS and Anna SCHNEIDER (2021)," Orientation of The Cultural Organisation Activity and It's Development Path", The Journal of Organizational Management Studies, Vol. 2021 (2021), Article ID 906718, DOI: 10.5171/2021.906718 


\section{Introduction}

The history of every organisation can determine and evidence through time its own evolutionary development. The nature of this evolution is influenced by a variety of determined factors both internal and external. In theory these developments should drive the organisation closer to a desired conclusion, however in reality these advances do not always impact positively the profile of the organisation. Therefore, a more defined examination of the history of the organisation provides a clearer understanding of its evolution. This allows us to comprehend better those impacts that have had the most important effects at any given point in time and how these can future shape its desired targets. Earlier models of organisation development do not necessarily provide an accurate reflection of the organisation for a specific point in time. Therefore, developing a theoretical model of the organisation's development based on its orientation can provide a clearer understanding and picture of the successes or issues faced in any given point of its evolution. This model can be utilised for further organisation research purposes, and to identify the universal orientations of its development (Krzos, PiwoniKrzeszowska, 2018).

The article is a continuation of theoretical considerations and an extension of the exemplifications presented in the article titled "A conceptual pattern of organisational development path - the proposal and theoretical assumptions" that was published in "Przedsiębiorczość i Zarządzanie” (Krzos, Piwoni-Krzeszowska, 2018). The aim of the article is to identify the orientation elements describing the path of the cultural organisation's development, which will constitute the basis for developing the method and tools for measuring orientation of the cultural institution. The article is empirical. An exploratory, single case study was conducted to determine whether the assumptions about these orientations made by G. Krzos and E. PiwoniKrzeszowska in the context of the cultural organisation are correct (Krzos, PiwoniKrzeszowska, 2018).

\section{The basic theoretical background of the organisation's development path}

The development of the organisation is a multi-faceted process and as such there is no specific classification for its' description. Figuratively speaking we can describe the organisation's development as a progression of qualitative and quantitative measurements of various types at any given point whether these are positive or negative. (Krzos, Piwoni-Krzeszowska, 2018). The process may include changes in various areas of its' functioning (Adamik, Zakrzewska-Bielawska, 2014).

The substance of our deliberations are studies undertaken by N. Siggelkow (Siggelkow, 2001, 2002). However, their range is constrained to displaying the issues related to the organisation's development and any endeavour to mark out specific areas of development. The aforesaid studies do not include efforts to present descriptions of the overall direction of the organisation and any orientation variances over time.

Development can be considered in the following dimensions: economic, organisational, personal, informative, technical and production (Stabryła, 1995), and also from the financial and strategic perspective (Bratnicki and Austen, 2005). From a theological point of view, development should lead to the improvement of the organisation's position in the environment. And this, in addition to the development of the organisation's infrastructure, requires the development of products and markets (Flamholtz, Hua, 2003). Given the specificity of the cultural sector, researchers emphasized that marketing draws attention to the twintrack approach and takes the product and market orientation as two separate images (Burkiewicz, 2014). This has been supported by Sobocińska who says that "Contrary to production, product, or sales orientation, market orientation involves 
thinking about the way in which a market entity functions" (Sobocińska, 2019). Moreover, it is impossible to disregard the inter-organisational relations, which is evolving, and determines adaptation to changing resources needs (StańczykHugiet, 2013) and shapes the conditions of competition and cooperation (Czakon, 2012).

From the standpoint of the organisation's development path as the progression of the course and differences in the direction of its activities, the advancement of this gap appears to be a fundamental component of the functioning of the organisation's images, given that different companies consist of various images, which are utilised to describe their scope.

Based on the literature (e.g., Stabryła 1995, Bratnicki and Austen 2005, Flamholtz and Hua 2003, Siggelkow 2002), we can ask ourselves:

1. Should the cultural institution orientation set be limited to:
a) products/market;
b) processes;
c) functions;
d) projects;
e) innovations/technology;
f) geographic expansion;
g) networking?

2. How to undertake the measurement of each orientation?

Researching the solutions to these issues requires an approach utilising in-depth empirical study and refined measurement tools.

\section{Research Methodology}

The research assumption presumes that data are incomplete, but sufficient to describe the activities of the cultural institution and its set of orientations will be the baseline for relating the cultural organisation development path. This provided the basis for the theoretical model of the cultural organisation development path. As such, this focused on identifying a range of orientations and estimating them. Splitting this set of orientations was undertaken following various discussions and critiquing the literature. Therefore, the foundation for the description of the orientations is primarily in the direction of: products / market, processes, projects, functions, innovations/ technologies, geographic expansion or networking.

In order to undertake the measurement of these orientations, regardless of which should be elected for the presentation of the description of the organisation's activities, there is, at the same time, transparency in the option of structuring a combined measurement of each of these orientations. The measurement should be an indicator of the concentration of these orientations and the changes taking place throughout.

The following conventions were utilised for the undertaking of the orientations' measurement.

a) the dimensions of the product/market orientation can be: the number of products, the number of product modifications, the orientation of the organisational structure on the product,

b) the dimensions of process orientation can be: number of processes, number of process modifications, orientation of the organisational structure to the process,

c) the dimensions of function orientation can be: number of functions, number of function modifications, orientation of the organisational structure to functions,

d) the dimensions of project orientation can be: number of projects, number of project modifications, orientation of the organisational structure for projects,

e) the dimensions of the innovation/technology orientation can be: the number of innovative technological solutions used, the level of technological maturity, the 
number of patents, patent applications and know-how,

f) the dimensions of the geographic expansion orientation can be: the number of regional markets, the number of foreign markets,

g) the dimensions of network orientation can be: number of entities, frequency of relationships, nature of relationships, place in the network.

The incapacity to specifically define the cultural institution's development path, the inability to stipulate the research data, and the lack of provisions for the undertaking of its description, and fundamentally, the various inadequacies in theoretical clarifications determine the choice of the case study method. According to K.M. Eisenhardt (Eisenhardt, 1989) and R.K. Yin (Yin, 2013), case study is appropriate when it has relevance due to its' potential for generalization and when the research is unique and extreme.

Based on the previous conventions of the project, this research is exploratory and is a pilot study. It was the overview to the beginning of a multiple study. It is founded on a single case study, at the same time demonstrating whether the set of orientations made about the organisation's development do establish that the basis for the depiction of the path is accurate.

In the theoretical model of the organisation's development path organisations instigate a set of goals. Within the life cycle of organisation, relatively sudden and instrumental changes in the direction of the orientations can occur. This leads to the question: what evidence is apparent to determine that the intended aims have been achieved or not? The path of the organisation's development indicates the progression of the pathway and alterations in the direction of its activities which contain various images of the organisation which can be described succinctly using the orientation's dimensions set out by the organisation; what determined these alterations, and finally, whether such changes are caused by exceeding the numerous barriers to development that the enterprise faces on its path.

Key questions from the research methodology were posed:

1. What orientations of the cultural institution activity should be taken into account in order to comprehensively describe the picture of its development path?

2. Can the set of these orientations be limited, but sufficient to describe the functioning of the cultural institution, when it is included in the orientations for: products/market, processes, functions, projects, innovations/technologies, geographic expansion, networking?

3. How to undertake the measurement of these orientations?

The following data analysis methods were used in the study: referring to theoretical assumptions and participant observation, which took place in $2018 / 19$.

The main weakness of the applied research method is analytical generalization. Increasing the probability of its accuracy requires conducting iterative case studies in order to develop the concept of the cultural institution development path for further research and to generate a hypothesis about its model.

\section{Dimensions of the cultural institution orientations}

The cultural institution $X$ was established in the 1960s and is one of the leading ballet companies of the United Kingdom. The Company performs not only across the UK but also abroad. Its broad repertoire includes new versions of the classics, signature pieces by living choreographers, seminal pieces from the 20th century modern ballet canon and new commissions. Its primary aim is to provide programmes of world-class dance performance and educational activity at all scales. The cultural institution $X$ presents a 
wide range of dances to audiences across the country and abroad and employs 38 professional dancers, 65 staff members and a part-time freelance orchestra of up to 60 musicians.

\section{The dimensions of product orientation}

Indisputably, in the cultural sector, performance is perceived as a product and audience as a recipient/customer. Among the products offered by a cultural institution $X$ the products of high and mass culture are distinguished. The cultural institution $X$ delivers a comprehensive programme with a range of access point for people with all ages and abilities, from children to elderly people, from classical to modern pieces of art. Therefore, there is a need to adopt twin-track approach and expand a product orientation to: product orientation (traditional concept - high culture, mission fulfillment goal) and market orientation (modern concept mass culture, profits)

Authors have identified the following dimensions of a product orientation:

- number of high-culture orientated products,

- number of high-culture products' modifications.

Authors have also identified the following dimensions of a market orientation:

- number of products adapted to recipients' expectations,

- growth of participation in cultural events.

\section{The dimensions of process orientation}

The main process in a cultural institution $X$ is the creation of a dance production. The fundamental elements which comprise this dance production would include: choreography creation, music adaptation, costumes design, promotion and stage preparation. The leaders of the processes are the managers of the respective departments.
Therefore, the dimensions of process orientation have been listed as:

- number of main processes,

- number of support processes,

- number of functions associated with processes.

\section{The dimensions of function orientation}

The cultural institution $X$ as with the majority of cultural organisations has functional organisational structure. The main departments are: the board, artistic team, dancers, orchestra and administration.

The identified dimensions of function orientation are:

- number of functions (departments) in the organisational chart,

- number of modifications changing the functional character of organisational structure.

\section{The dimensions of project orientation}

During the research, it became clear that cultural projects are based on intuition and cultural institution $X$ own experiences rather than project management methodologies. Despite the lack of formal project management techniques, authors have recognized wide range of projects run by the institution. Apart from dance productions which are strategic projects, the institution has been implementing educational, digital and interdisciplinary projects.

The following dimensions of project orientation have been recognised by authors:

- number of strategic projects,

- number of operational projects,

- number of interdisciplinary projects. 


\section{The dimensions of the innovation and technology orientation}

The digital infrastructure and skills have indisputably been the strength of the institution. The openness of the entire organisation to new technologies and nontraditional ways of creating work acquired new online content and developed relationships with digital partners. With the spread of the Covid-19 pandemic, the cultural sector has noted lots of cancelations and postponements. "Out of the box thinking" has always been a strong feature of the cultural institution $X$. Recognising the damage the cultural institution $X$ could face, existing digital event formats have been further improved and implemented.

Authors have identified the following dimensions of innovation and technology orientation:

- number of implemented innovations,

- the level of technological maturity.

\section{The dimensions of the geographic expansion orientation}

The cultural institution $X^{\prime}$ 's long history includes touring across the country and invitations to international arts events. As part of these cultural exchanges, international guests are invited to perform with the cultural institution $X$.

Therefore, the following dimensions have been identified:

- number of national performances,

- number of international performances,

- number of artists/institutions visiting and performing with the cultural organisation.

\section{The dimension of networking orientation}

The cultural institution $X$ plays an integral role in the cultural networks. High level cooperation between the cultural institution $X$ and other cultural institutions and art universities worldwide has produced the range of innovative artistic projects followed by long-term relationships. Thanks to this, joint degree programmes have been established between cultural institution $X$ and the educational sector. Moreover, strong focus is laid on collaboration with sponsors and donors.

Therefore, the following dimensions have been identified:

- number of strategic partners,

- number of long-term relationships with stakeholders.

\section{Discussion on the results}

The empirical study confirms that the established set of orientations of the organisation's activity describing the path of its development can be applied to the cultural institution. (Krzos, PiwoniKrzeszowska, 2018). The study showed that the development of cultural institution $X$ covers complementary changes in various spheres and areas of its functioning, which is in line with the view of A. Adamik and A. Zakrzewska-Bielawska (2014).

However, it should be emphasized that this study is a pilot study, so it can be concluded that the orientations of the cultural institutions activity that should be taken into account to describe the picture of its development path are:

- product orientation that has been highlighted by A. Stabryła (1995) and E. Flamholtz and W. Hua (2003); market orientation, which has been emphasized by Burkiewicz and Sobocińska,

- focus on processes, functions and projects in the context of organisation development indirectly mentioned by A. Stabryła (1995) and E. Flamholtz and W. Hua (2003),

- innovation/technology orientation and the relevance of the technological dimension of development, which has also been emphasized by A. Stabryła (1995),

- orientation towards geographical expansion, which has been reflected 
in the opinion of E. Flamholtz and W. Hua (2003),

- network orientation, which is in line with the view of E. Stańczyk-Hugiet (2013) that one cannot detract from inter-organisational relations, which are evolving, and determine adaptation to the changing resources needs.

Nevertheless, the question of how to describe the orientations of the cultural institution activity reflecting the path of its development remains open. At this stage of research, one can only assume that the set of these orientations is sufficient, but it is not limited. The research results also show that the dimensions of cultural institution orientation are not the same as the assumptions made. This indicates the need for further, in-depth research in this field and prompts to consider, whether there is a common set of dimensions describing individual orientations, whether it is perhaps determined by the specificity of the cultural institution activity, e.g., size or type of the institution. Therefore, the analytical generalization of this conclusion requires further research in the form of multiple case studies, which should be conducted within cultural institutions of different sizes and types.

The open question about the implementation of the orientation of the cultural institution's activity, reflecting the path of its' development inspires to set the question, whether it is possible to build an aggregate measure of each of these orientations, which would indicate their relevance and the changes taking place in them.

\section{Conclusions}

Literature reviews have shown that there is a research gap in the field of cultural organisation's development path. A singlecase study confirmed that sufficient but not limited set of orientations describing the path of cultural institution development includes product/market, process, function, project, innovation/technology, geographic expansion and networking orientations. The question about the undertaking measurement of these orientations remains open. Filling in this gap requires further qualitative empirical research. The results obtained from this research should become a subject to further quantitative research, which would also provide an answer to the question of whether it is possible to propose a universal set of orientations for the cultural institution's activity, which could be used to present and discuss its development paths. Further longitudinal research would enable the presentation of development paths of cultural institution and identification of possible accuracy in their course within the studied population. The empirical research discussed in this article indicates the directions of future research on the paths of cultural organisation development in the methodological and empirical layer.

\section{References}

- Adamik, A. and Zakrzewska-Bielawska, A. (2014), Istota rozwoju przedsiębiorstw high-tech, [w:] A. Zakrzewska-Bielawska (red.), Koopetycja w rozwoju przedsiębiorstw high-tech. Determinanty i dynamika, Wydawnictwo Placet, Warszawa, 1062.

- Bratnicki, M. and Austen, A. (2005), Strategia ogniw pośrednich, czyli przedsiębiorcze uczenie się przez porażkę, [w:] R. Krupski (red.), Zarządzanie strategiczne. Strategie małych firm, Prace Naukowe Wałbrzyskiej Wyższej Szkoły Zarządzania i Przedsiębiorczości, Wałbrzych. 224, 233-250.

- Burkiewicz, Ł. (2014), Marketing w kulturze. Ukierunkowanie na rynek czy na produkt? (= Marketing in culture. Market or product orientation?), Perspektywy kultury, 2 (11), 141-156, 171

- $\quad$ Czakon, W. (2012), Sieci w zarządzaniu strategicznym, Wolters Kluwer Polska, Warszawa, 55-58.

- Eisenhardt, K.M. (1989), Building theories from case study research. Academy of Management Review 14(4), 532-550. 
- Flamholtz, E. and Hua, W. (2003), Searching for competitive advantage in the black box, European Management Journal, 21(2), 222-236.

- Krzos, G. and Piwoni-Kreszowska, E. (2018), Konceptualny wzorzec ścieżki rozwoju przedsiębiorstwa opartej na kluczowych orientacjach - założenia teoretyczne i próba jego weryfikacji, Przedsiębiorczość i zarządzanie XIX (6), Budzanowska-Drzewiecka, M. (ed), Wydawnictwo Społecznej Akademii Nauk, Łodz.

- Obłój K. (2017), Praktyka strategii firmy. Jak zarządzać przeszłością, radzić sobie $\mathrm{z}$ teraźniejszością i tworzyć przyszłość, Wydawnictwo Poltext, Warszawa.

- Siggelkow, N. (2001), Change in the presence of fit: the rise, the fall, and the renaissance of Liz Claiborne, Academy of Management Journal, 44(4), 838857.

- $\quad$ Siggelkow, N. (2002), 'Evolution toward Fit', Administrative Science Quarterly, 47, 125-159.

- Sobocinska, M. (2019), The Role of Marketing in Cultural Institutions in the Context of Assumptions of Sustainable Development Concept-A Polish

Case Study. Sustainability 2019, 11, 3188.
- Stabryła, A. (1995), Zarządzanie rozwojem firmy, Księgarnia Akademicka, Kraków, 7.

- Stańczyk-Hugiet, E. (2013), Dynamika strategiczna w ujęciu ewolucyjnym, Wydawnictwo Uniwersytetu Ekonomicznego we Wrocławiu, Wrocław, 121

- Van de Ven, A. and Poole, M. (1995), Explaining developmental and change in organizations, Academy of Management Review, 20 (3), 510-540.

- Vergne, J. and Durand, R. (2010), The missing link between the theory and empirics of path dependence: conceptual clarification, testability issue, and methodological implications, Journal of Management Studies, 47 (4) 736-759.

- Yin, R.K. (2013), Case study research: Design and methods. Thousand Oaks, CA: Sage Publications. 